\title{
A COMPARATIVE ANALYSIS OF THE GASTRO-INTESTINAL HELMINTH PARASITES OF CATTLE IN AWKA AND OBOSI ABATTOIRS IN ANAMBRA STATE, SOUTHEASTERN NIGERIA.
}

\author{
Umeanaeto, P.U., ${ }^{1}$ Ogbogu, N.E., ${ }^{2}$ Irikannu, K.C., ${ }^{3 *}$ Onyido, A.E. ${ }^{4}$, Okwelogu, I.S., Mbanefo ${ }^{5}$, E.C., ${ }^{6}$ and \\ Ifeanyichukwu, M.O. ${ }^{7}$ \\ *1,2,3,4,5,6 Department of Parasitology and Entomology, Nnamdi Azikiwe University Awka, Anambra State. \\ ${ }^{7}$ Department of Medical Laboratory Sciences, Nnamdi Azikiwe University Awka, Anambra State.
}

*Corresponding Author: -

Email: kayceeirika@yahoo.com

\begin{abstract}
: -
A comparative study was carried out on the prevalence of gastro-intestinal helminthes of cattle in Awka and Obosi abattoirs in Anambra State, between August and September, 2014. Fresh faecal specimens were collected from the rectum of 120 fleshly slaughtered cattle using universal specimen containers. Parasitological examination of the faeces was done using direct smear and formal-ether concentration techniques. Out of 120 faecal specimens examined, 53(44.2\%) of the cattle harboured gastro-intestinal helminth parasites. The prevalence of the intestinal parasites was higher in Obosi abattoir 33(55.0\%) than in Awka abattoir 20(33.3\%). The highest intestinal parasite encountered was nematode infection (26.7\% in Awka; $31.7 \%$ in Obosi) and the least was cestode (15.0\% in Awka; 21.7\%in Obosi). Among the nematodes, Haemonchus contortus was common (10\% in Awka; $11.7 \%$ in Obosi). Mixed infection recorded were 13.3\% in Awka and $18.3 \%$ in Obosi abattoirs. White Fulani species had the highest infection rate in both Awka 10(16.7\%) and Obosi abattoirs 14(23.4\%) while the Red Fulani had the least prevalence in Awka3(5.0\%) and Bokolo species 8(13.4\%) in Obosi. Prevalence according to gender showed that females (20.0\% in Awka; $28.3 \%$ in Obosi) were more infected than the males (13.3\% in Awka; 26.7\% in Obosi). The prevalence of gastro-intestinal parasites was observed to be statistically significant with gender $(P>0.05)$ but not with different breeds $(P<0.05)$. Good management practices in cattle rearing will help to reduce intestinal parasites of cattle.
\end{abstract}

Keywords: Comparative, gastro-intestinal, helminthes, infection, cattle, abbatoir, Awka, Obosi,

\section{(c) $(\$)$}




\section{INTRODUCTION}

Livestock production constitutes a very important component of the agricultural economy of developing countries, a contribution that goes beyond direct food production to include multipurpose uses, such as skins, fibre, fertilizer and fuel, as well as capital accumulation [1]. Furthermore, livestock are closely linked to the social and cultural lives of several million resource-poor farmers for whom animal ownership ensures varying degrees of sustainable farming and economic stability [2]. Cattle are distributed in many parts of the world including Nigeria and the distribution is in such a way that up to ten cattle is kept per household in the Northern part of Nigeria [3]. Cattle are slaughtered on daily basis in all abattoirs in Nigeria, where they are sold as beef to the public. This accounts for upto $70 \%$ of the total meat consumed in the country [4].

Apart from these advantages, cattle are infected with gastrointestinal parasites especially helminthes [5].Gastrointestinal helminth infections are recognized as a major constraint to livestock production throughout the tropics and elsewhere [6]. Intestinal helminthes are worldwide problem for both small and large scale cattle farmers but its impact is greater in subSaharan Africa and Nigeria in particular. This is due to availability of diversified host and parasites species [7].

The gastro-intestinal helminthes populate the gastro-intestinal tracts of cattle and other associated organs of GIT. The parasites live in the host, receiving nourishment and protection while causing acute and chronic infections, disrupting the host nutrient absorption, causing reduced weight gain, reduced food conversion, abortion, infertility, reduced meat and milk production, weakness and diseases [8]. However, the effect of helminth infections is determined by a combination of factors, of which the varying susceptibility of the host species, the pathogenicity of the parasite species, the host/parasite interaction, and the infective dose are the most important [9].

Knowledge of the intestinal helminthes parasites of animals is of great value particularly in the field of veterinary medicine, animal parasitology and zoonoses. The negative impact of helminth infection on livestock productivity in Nigeria has been established in the reports of $[10,11,12,13,14]$.

The most important predisposing factors of helminth infections are grazing habits (feeding on contaminated pastures and feeding or drinking from a contaminated water source), climate, nutritional deficiency, pasture management, immunological status, vector or presence of intermediate host and the number of infective larvae and eggs in the environment [15]. The helminth infection of ruminants are mostly caused by nematodes (Ostertagia spp., Capillaria spp, Trichuri spp, Strongyloide spp), cestodes (Monieza spp, Taenia spp) and Trematode (Dicrocoelium spp, Fasciola gigantica, Amphistomes) [16, 17]. The objective of this research is to investigate the gastrointestinal helminthes of cattle in the two selected abattoirs in Anambra State. The result of this study will enhance diagnosis for planning control measures of helminth infections in cattle.

\section{MATERIALS AND METHODS A. Study area}

This study was carried out at the two selected abattoirs in Anambra State (Awka and Obosi abattoirs). Awka abattoir is located in Awka which is the capital city of Anambra State while Obosi abattoir is located in a semiurban community of Obosi. Cattle slaughtered in these abattoirs are mostly sourced from different cattle rearing regions of Nigeria (mainly Northern Nigeria). Due to their location and large number of animals slaughtered, these abattoirs serve as major sources of meat consumed in Anambra State, a state with a population of about 4.2 million people [18]. The indiscriminate refuse disposal and poor drainage accounts for the poor sanitation and thus, enhance the dissemination of parasitic infection.

\section{B. Faecal Sample Collection and Identification}

Simple random sampling method was used in selecting cattle that were screened at antemortem. Fresh faecal samples were collected from the rectum of freshly slaughtered cattle into a well-labeled universal specimen container containing $10 \%$ formalin as preservative. For each animal screened, parameters such as the sex and breed were recorded. The specimen were transported to the laboratory of the Department of Parasitology and Entomology, Nnamdi Azikiwe University, Awka where they were examined for helminth egg using direct saline method and formal-ether sedimentation methods [19]. Eggs were identified on the basis of their morphological features as described by [20].

\section{Data Analysis}

Data were subjected to statistical analysis using percentages in determining the prevalence rates in the different breeds, sex, and location of the abattoirs. Chi square statistical test was used to compare and determine the significance of the prevalence in the two locations as well as the sex and breeds of the cattle.

\section{RESULTS}

Out of the 120 faecal specimens examined (60 cattle from each location), 53(44.2\%) of the cattle were infected with gastro-intestinal helminth parasites. cattle were more infected in Awka abattoir 20(33.3\%) than in Obosi abattoir $33(55.0 \%)$. The distribution of helminthes in different locations of the abattoirs is statistically significant $(\mathrm{P}<0.05)[$ Table 1]. White Fulani had the highest prevalence [Awka $=10(16.7 \%$; Obosi=14(23.3\%)] while Red Fulani 3(5.0\%) had the least in Awka and Bokolo8(13.3\%) had the least in Obosi abattoir, although the result was not statistically significant $(\mathrm{P}>0.05)$ [Table 2]. Intestinal nematodes were more common in both abattoirs [Awka; 16(26.7\%), Obosi; 19(31.7\%)] than other helminthes. Haemonchus contortus was the highest species of nematode encountered while Trichuris globulosa was the least (Figures 1-3). 
Table 1: Prevalence of intestinal helminthes in different locations of the abattoirs.

$\chi^{2} \mathrm{cal}=4.5>\chi^{2}$ tab $=3.84 \mathrm{df}: 1(\mathrm{P}<0.05)$

\begin{tabular}{|l|l|l|l|}
\hline Study area & Number positive (\%) & Number negative $(\%)$ & TOTAL \\
\hline Awka abattoir & $20(33.3)$ & $40(33.3)$ & 60 \\
\hline Obosi abattoir & $33(55.0)$ & $27(45.0)$ & 60 \\
\hline Total & $53(44.2)$ & $67(55.8)$ & 120 \\
\hline
\end{tabular}

Table 2: Prevalence of intestinal helminthes in relation to the breeds (species) of the cattle

\begin{tabular}{|l|l|l|l|l|}
\hline & AwkaObosi & \\
\hline Cattle species & $\begin{array}{l}\text { No. of cattle } \\
\text { examined }\end{array}$ & No. positive (\%) & $\begin{array}{l}\text { o. of cattle } \\
\text { examined }\end{array}$ & No positive (\%) \\
\hline White Fulani & 23 & $10(16.7)$ & 26 & $14(23.3)$ \\
\hline Red Fulani & 19 & $3(5.0)$ & 20 & $11(18.3)$ \\
\hline Bokolo & 18 & $7(11.7)$ & 14 & $8(13.3)$ \\
\hline Total & 60 & $20(33.3)$ & 60 & $33(55.0)$ \\
\hline
\end{tabular}

$\chi^{2}$ cal $=1.53<\chi^{2}$ tab $=5.991 \mathrm{df}: 2(\mathrm{P}>0.05)$

Table 3: Prevalence of intestinal helminthes in relation to gender of the cattle.

\begin{tabular}{|l|l|l|l|l|l|l|}
\hline \multirow{2}{*}{$\begin{array}{l}\text { Gender } \\
\text { Cattle }\end{array}$} & \begin{tabular}{l} 
Awka abattoir \\
\cline { 2 - 7 } \\
Examined
\end{tabular} & No. Positive & $\begin{array}{l}\text { No. } \\
\text { Negative }\end{array}$ & $\begin{array}{l}\text { No. } \\
\text { Examined }\end{array}$ & $\begin{array}{l}\text { No. } \\
\text { Positive }\end{array}$ & $\begin{array}{l}\text { No. } \\
\text { Negative }\end{array}$ \\
\hline Male & 35 & $8(13.3)$ & $27(45.0)$ & 28 & $16(26.7)$ & $12(20.0)$ \\
\hline Female & 25 & $12(20.0)$ & $13(21.7)$ & 32 & $17(28.3)$ & $15(25.0)$ \\
\hline Total & 60 & $20(33.3)$ & $40(66.7)$ & 60 & $33(55.0)$ & $27(45.0)$ \\
\hline
\end{tabular}

$\chi^{2}$ cal $=4.42>\chi^{2}$ tab $=3.84 \mathrm{df}: 1(\mathrm{P}<0.05)$

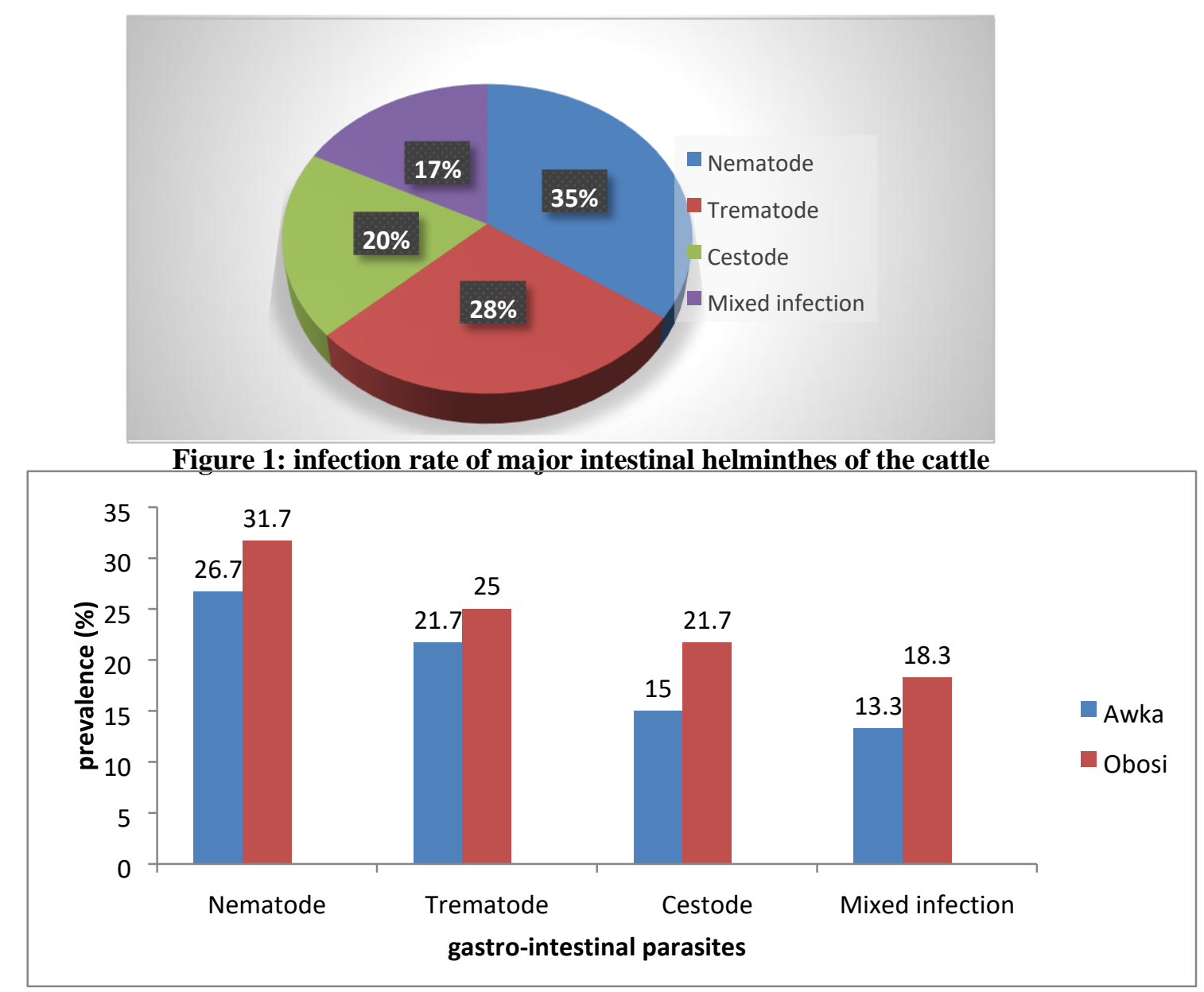

Figure 2: Distribution of different species of intestinal parasites in the different abattoirs. 


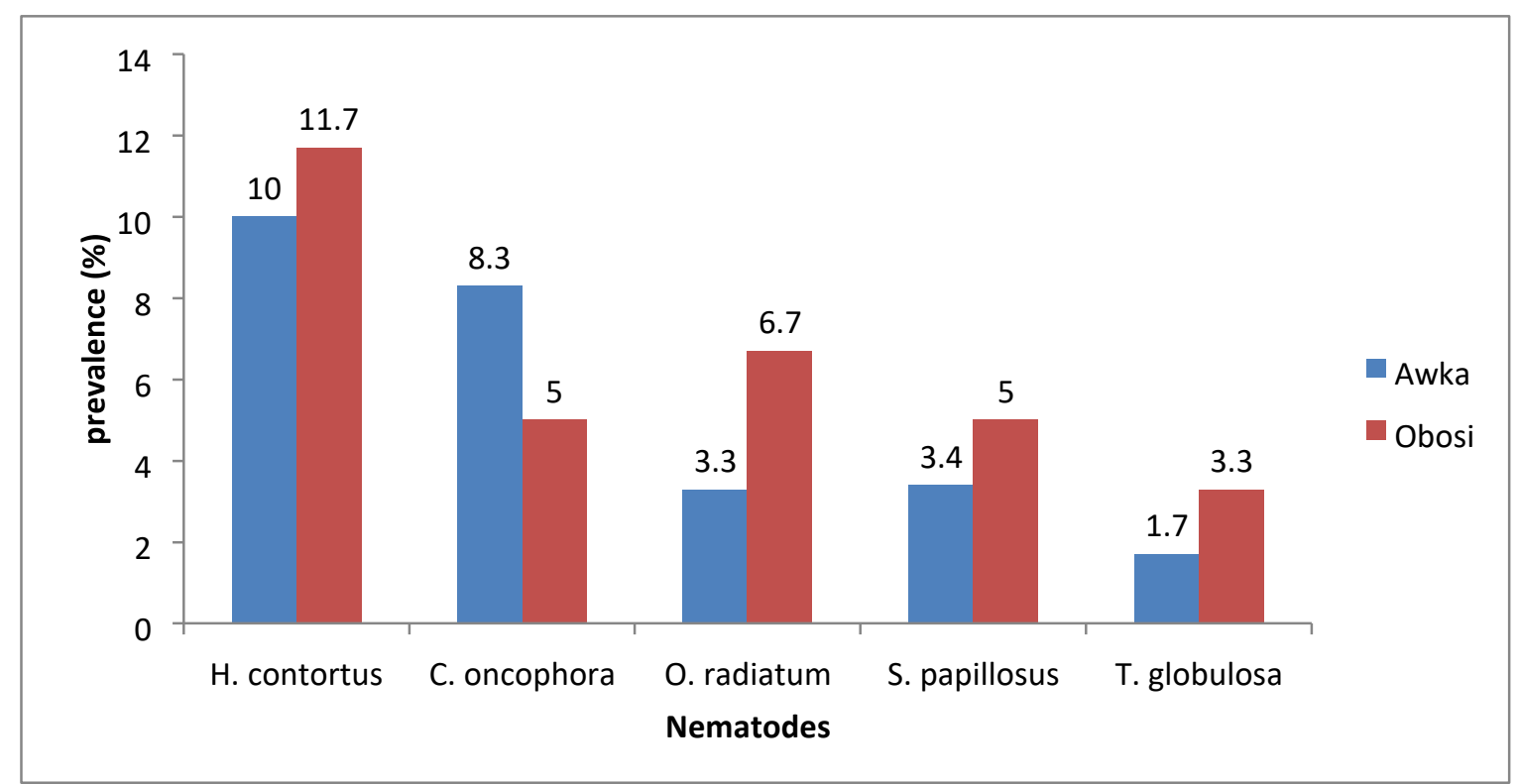

\section{DISCUSSION}

Figure 3: Different nematode species encountered in the study areas.

The result of this research indicated infection of the cattle with gastro-intestinal helminth hence a prevalence rate of 53 (44.2\%), thus providing valuable information on the burden of helminths among cattle not only in Anambra State but in Nigeria at large since animals slaughtered in these abattoirs are representative of cattle in the country. This result was lower than $47.4 \%, 50.8 \%, 46 \%$ and $62.1 \%$ reported by [13,14,21,22] in Benin, Abakaliki, Ibadan and Pot Harcourt respectively. The differences observed could be due to the periods or seasons in which the studies were conducted as well as the sources of cattle sampled in the various regions. It could also be attributed to the existence of favorable environmental factors necessary for the prolonged survival and development of infective larval stage of most helminths [23]. Furthermore, management system of animals could also be accountable for the difference in prevalence [24].

Since all animals examined were matured, it was not possible to establish age-prevalence relationship. White Fulani breed had the highest prevalence while Red Fulani and Bokolo had the least in Awka and Obosi abattoirs respectively. [25] included breed of animals among other risk factors associated with gastrointestinal parasites, although the statistical analysis from this survey showed that prevalence of the intestinal parasites was not dependent on the breed, $(\mathrm{P}>0.05)$ but on the sex and location $(\mathrm{P}<0.05)$. This could be as a result of poor sanitation and poor management practices among the cattle keepers. Awka abattoir being in the urban area has higher hygienic standard than the Obosi abattoir which is located in semi-urban area. There is presence of the slow moving Idemmili stream at the Obosi abattoir site where the carcasses of the cattle are washed into and the cattle are fed with the same water too thus contributing to higher infection of the intestinal helminthes in Obosi than Awka. The higher infection among the females could be as a result of reduced immunity attributed to the physiological changes like pregnancy and lactation stress in females.

Presence of mixed infection in this study poses a great risk to the cattle. Mixed infection has been suggested to be an important cause of morbidity and reduced production in livestock [26] Furthermore, the immuno suppression of the host immune system by mixed infections increases host susceptibility to other diseases or parasites [27].

The high prevalence of nematode especially Haemonchus contortus may be attributed to the non-use of anthelmintic drugs by livestock farmers or effect of anthelmintic resistance [28] or climate [29]. These parasites (Haemonchus contortus, C. oncophora, O. radiatum, T. globulosa), trematodes (Fasciola gigantic and Paramphistomum spp.) and cestodes (Monieza spp.) recorded in this study were the common helminthes of cattle as recorded by [14] and [13] in Abakiliki and Benin respectively. Tropical climate provide a conducive atmosphere for the development of these parasites. Biologically, the highest health risk is found in helminth infections compared with other pathogens because helminthes especially nematodes persist for longer periods in the environment and the infective dose is small [29].

The present study was done during the warm period of the rainy season, though did not focus on the seasons, it has been established that the excretion of parasite eggs to environment by human or animals is high in warm seasons compared to cold seasons [30]. [31] stated that nematodes are among the most successful parasites of animals because of their efficient life cycle ranging from the very simple to the extremely complicated stage. Economically, parasitic infections have continued to be a major barrier to livestock. These intestinal parasites especially helminthes, pose a threat in the animal health and bring about a reduction in the quantity of much needed protein driven from animals. The regular use of antihelmintic drug is advocated even when the animals show no clinical signs of disease. Better breeding should be adopted and good nutritional status of animals maintained.

\section{REFERENCES}

[1].Food and Agricultural Organisation (1992). The role of ruminant livestock in food security in developing countries. FAO Committee on World Food Security, 17th Session, 23 to 27 March 1992, Rome, Italy: pp 33.

[2].Food and Agricultural Organisation (1993). Strategies for sustainable animal agriculture in developing countries. Proceedings of the FAO Expert Consultation held in Rome, Italy, 10 to 14 December 1990. Edited by S. Mack. FAO Animal Production and Health Paper No. 107. Rome, FAO. 271 pp. 
[3].T.A Adegbola (1982). The feeding and nutrition of small ruminants. Proceedings $2^{\text {nd }}$ National Workshop on small ruminant diseases and reproduction. University of Nigeria, Nsukka: 20-21.

[4].B.M Anene, T.O Onyekwodiri, A.B Chime, and S.M Anika (1993): Gastro-intestinal parasites in sheep and goats of Southeastern Nigeria. Small Ruminant Elsevier Science 13, (Issue 2): 187-192.

[5].M.B Anaeto, G.I Tayo, G.O Chioma and A.A Afolabi (2009).comparative study of Albandazole and C. papaya seed on the control of gastrointestinal nematodes in goats. Journal of Life and Physical Sciences, ACTA SATECH 3(1): 2528

[6].J.B Githiori, S. Hogland, P.J Waller and R.L Baker (2004): Evaluation of anthelmintic properties in some plants used as livestock dewormers against Haemonchus contortus in sheep. Parasitol,129:245253.

[7].M.A Morales, J. Luenge, and J. Vasguez (2000): Distribution and prevalence of roundworm in male animal in Chile, 1989-1995. Parasitology-aldia, 24:3-4, 115-118.

[8].D. Beriajaya, E.S Estuningsh, M.R Darmono, M. Knox, D.R Stoltz, and A.J Wilson, (1995). The use of wormala in controlling gastrointestinal nematode infection in sheep under traditional grazing management. Indonesia Journal HmuTermakdanveterineer 13: 49-55

[9].Food and Agricultural Organisation (2000). Distribution and impact of helminth diseases of livestock in developing countries, in FAO Corporate Document Repository-Agriculture and Consumer Protection.

[10]. I.O Onyali, C.O.E Onwaliri, and J.A Ajayi (1989). Strongyloides papillosus Infections of lamb in Plateau State of Nigeria. Revise d' Elevage et-de-medicine-vatennar-des-pays-tropicaux,42:223-226.

[11]. H.Y Aliyara, C.O Nwosu and M.B Ardo (2012): Prevalence and Seasonal Changes in Helminthes of cattle in Nigeria. Veterinary Research, 5:46-49

[12]. E.U Edosomwan and T.J Ewarami (2012). Ticks and helminth parasites of cattle at Ikpoba Hill abattoir Benin City, Edo State, Nigeria. Biological and Environmental Sciences Journal for the Tropics 9(1): 179-183.

[13]. E.U Edosomwan and O.O Shoyemi (2012): Prevalence of Helminthes Parasites of Cattle and goats slaughtered at abattoir in Benin City. African Scientist, 13(2): 1595-6881

[14]. J.O Nwigwe, O.O Njoku, O.O Odikamnoro and C.A Uhuo (2013). Comparative study of intestinal helminths and protozoa of cattle and goats in Abakaliki metropolis of Ebonyi State, Nigeria. Advances in Applied Science Research, 4 (2): 223-227.

[15]. O.M Radostits, D.C Blood and C.C Gay (1994). Diseases caused by helminth parasites in Veterinary Medicine: A Textbook of Diseases of Cattle, Sheep, Pigs, Goats and Horses, pp. 1223-1230, Bailliere Tindall, London, UK, 8th edition, 1994.

[16]. S.N Chiejina (1987): Parasitic Gastro-enteritis in Cattle and Small Ruminants: Pathogenesis Diagnosis and Treatment. Zariya Veterinary, 2:45-64.

[17]. A.I Zahid and K.B Baloch (2005). Incidence of endo parasites in exotic cattle calves. Pakitan Veterinary Journal 25(1): 47-48

[18]. NPC/FRN, (2006). Population Census of Nigeria, Federal Republic of Nigeria. Population distribution in Local Government Areas by Sex and Number of Households. Legal Notices on publication of the details of the breakdown of the National and State Provisional population census totals. Official Gazette, 94(24).

[19]. M. Cheesbrough (2006). Examination of blood for malaria parasite. District Laboratory Practice in Tropical Countries Part 1. Cambridge Low-Price Edition: 239-258.

[20]. E.J.L Soulsby (1982). Helminths, Arthropods and Protozoa of Domesticated Animals, Bailliere Tindall, London, UK, 7th edition.

[21]. A.D Olubukola, E.C Uwalaka, V.O Akinseye, O.A Adediran, S. Idowu and B. Cadmus, (2014). Gastrointestinal helminthes in Slaughtered Cattle in Ibadan, South-Western Nigeria. Journal of Veterinary Medicine (ID923561): 16

[22]. K. Elele, O. Owhoeli, and L.B Gboeloh (2013). Prevalence of species of helminthes parasites in cattle slaughtered in selected abattoirs in Port Harcourt, south-south, Nigeria. International Research on Medical Sciences 1 (2): 1017

[23]. C.E Rossanigo and L. Gruner (1995). Moisture and temperature requirements in faeces for the development of freeliving stages of gastrointestinal nematodes of sheep, cattle and deer," Journal of Helminthology, 69 (4):357-362).

[24]. F. Regassa, T. Sori, R. Dhuguma and Y. Kiros (2006). Epidemiology of gastrointestinal parasites of ruminants in Western Oromia, Ethiopia. International Journal of Applied Research of Veterinary Medicine, 4(1): 51-57.

[25]. R. Fikru, S. Teshal, D. Reta, and K. Yosef (2006): Epidemiology of gastro-intestinal parasites of ruminants in Western Oromia, Ethiopia. International Journal of Appl. Kes. Vet. Med., 4(1):51-57.

[26]. B. Kumsa, T. Tadesse, T. Sari, R. Duguma, and B. Hussen (2011). Helminths of sheep and goats in Central Oromia (Ethiopia) during the dry season. Journal of Animal and Veterinary Advances 10(14): 1845-1849.

[27]. C.R Wang, J.H Qiu, J.P Zhao, L.M Xu, W.C Yu and X.Q Zhu (2006). Prevalence of helminths in adult dogs in Heilongjiang Province, the People's Republic of China.Parasitology Research 99(5): 627-630.

[28]. J.W Magona and G. Musisi (1999). Prevalence and infections level of gastrointestinal nematodes in Ugandan goats in different agro climate zones. Bulletin of Animal Health Production Africa 47: 49-56.

[29]. P. Gaspard, J. Wiart and J. Schwartzbrod (1997). Parasitological contamination of urban sludge used for agricultural purposes. Wast Manage Res, 15: 429-436.

[30]. E. Kozan, F.K Sevimli, M. Köse, M. Eser and H. Ciçek (2007). Examination of helminth contaminated wastewaters used for agricultural purposes in Afyonkarahisar. TurkiyeParazitolDerg, 31 (3): 197-200

[31]. J.D Smyth (1996): Animal Parasitology. Great Britain University Press Cambridge, 205-206. 